\title{
Luther and the Reading of Scripture
}

\section{Saarinen, Risto Juhani}

Fortress Press

2017

Saarinen, R J 2017 , Luther and the Reading of Scripture . in D Marmion, S Ryan \& G E Thiessen (eds), Remembering the Reformation : Martin Luther and Catholic Theology . Fortress Press, Minneapolis, pp. 193-209.

http://hdl.handle.net/10138/310404

acceptedVersion

Downloaded from Helda, University of Helsinki institutional repository.

This is an electronic reprint of the original article.

This reprint may differ from the original in pagination and typographic detail.

Please cite the original version. 
Luther and the Reading of Scripture

Risto Saarinen

I

The emerging Lutheran Reformation adopted the view that all doctrine should be based on the canonical books of Holy Scripture. In addition, Luther considered that all believers should be able to read the Bible in their own language. Luther's translation of the German Bible provided a model that was followed through Europe. Luther is critical of medieval allegorical interpretations of biblical texts and recommends literal understanding. He nevertheless also provides expositions that employ allegory and typology. Luther's relationship to the later emergence of the historical critical reading of the Bible is complex. Reformation writers do not have the kind of historical awareness that the first biblical scholars of the Enlightenment possess. Luther and his followers were, however, influenced by the Humanist movement in several ways; the Humanist call ad fontes, to the original sources, was often invoked in the European Reformations. ${ }^{1}$

In addition to the literalist and Humanist reading of the Bible, Martin Luther's approach contains a strong first person-emphasis on the subjective involvement of the believer. The biblical word is meant for me personally and should be applied to my own life. German scholars have often labeled this feature as Luther's existential understanding of the Bible, a method that connects him with later evangelical revivals as well as with the Enlightenment

${ }^{1}$ See Robert Rosin, "Humanism, Luther, and the Wittenberg Reformation", in The Oxford Handbook of Martin Luther's Theology, ed. R. Kolb et al. (Oxford: Oxford University Press, 2014), 91-104, and Oswald Bayer, Martin Luther's Theology (Grand Rapids: Eerdmans, 2007), 68-92. 
understanding of individuality. Some scholars have seen here an affinity between Luther and Kierkegaard or Luther and twentieth century existential philosophy. ${ }^{2}$

Historically, however, the personal application of the word is nothing new in Christianity or Western thinking in general. If we look at the Spiritual Exercises of Ignatius of Loyola, Luther's contemporary, we can see that the personal application and appropriation of biblical truths in essential for Catholic spirituality as well. Historians of philosophy have paid attention to the Hellenistic idea of philosophy as a way of life, that is, not only theoretical endeavor but also a practical technique of developing the personal self. Already ancient philosophers, like Cicero, outline the so-called oikeiosis or commendation, the view regarding how the primary attachment of a person to her own body and soul develops. According to Cicero, the need for self-preservation and the attachment to one's own body are the primary events from which an individual starts the development of her desires and social needs as well as the care for her own body and soul. This tradition is continued and transformed in later Christianity. ${ }^{3}$

While paying attention to such traditions is important, Luther's reading of the Bible is also distinctive. To see how it is distinctive, we need to look briefly at his reading of some concrete biblical themes. For this exercise I have chosen the well-known controversy between Luther and Erasmus on free will. This controversy starts with Erasmus' De libero arbitrio in 1524. In this work Erasmus criticizes Luther's denial of free will presented in his early writings, especially the so-called Assertio of 1521. Erasmus adopts Luther's view of the

\footnotetext{
${ }^{2}$ Lennart Pinomaa, Der existenzielle Charakter der Theologie Luthers (Helsinki: AASF, 1940). Otto Hermann Pesch, Die Theologie der Rechtfertigung bei Martin Luther und Thomas von Aquin (Mainz: Grünewald, 1967). ${ }^{3}$ See Risto Saarinen, "Das glaubende Subjekt und die Ökumene", to appear in Luther, Katholizität und Reform, ed. W. Thönissen (Paderborn: Bonifatius). I here argue against Paul Hacker, Das Ich im Glauben bei Martin Luther (Graz: Styria, 1966). The relevant places in Cicero include De officiis 1,7; 1,21 and De finibus 2,35; 3,$16 ; 3,63-65$.
} 
Bible as the sole authority in doctrinal matters as the starting-point of his own, more positive, view of free will. In the following I will first present Erasmus' biblical interpretation very briefly and then investigate Luther's reading of the Bible in his response to Erasmus' De servo arbitrio (1525)

\section{II}

Erasmus proceeds carefully in the issue of free will. He considers is aware that eld earlier Christian authors had written about this issue in various ways. ${ }^{4}$ Erasmus wants to ascribe some power and freedom to the will. He takes distance from Wycliffe's view of predestination, but he is also critical of Pelagius and does not seem to approve of the voluntarist view of John Duns Scotus. For Erasmus, while there is some room for free will, grace is the most important power of salvation. ${ }^{5}$

The biblical arguments of Erasmus proceed from the insight that moral responsibility assumes some freedom of the will. When God left the human being to rely on human decision, some merit and some culpability as well as some freedom could be ascribed to this decision. ${ }^{6}$ Erasmus presents a great amount of biblical sentences that speak about moral willing in this sense. For instance, Jesus often appeals to the human will in the Gospel of Matthew. This gospel also contains different kinds of exhortations and commandments which do not make sense if the human being has no power to respond to them. ${ }^{7}$ In his biblical expositions Erasmus appeals to common sense: voluntary actions and exhortations to will something simply assume that there is a will that is capable of doing what is required.

\footnotetext{
${ }^{4}$ Erasmus, De libero arbitrio, Ausgewählte Schriften 4 (Darmstadt: Wiss. Buchgesellschaft, 1969), Ia5.

${ }^{5}$ Erasmus, IV16.

${ }^{6}$ Erasmus, IIa1.

${ }^{7}$ Erasmus, IIb1-2.
} 
Biblical sentences that express voluntary behavior need to be understood in this manner, as this is the way how such propositions are commonly understood. ${ }^{8}$

Philosophically speaking, Luther's and Erasmus' views are, in fact, compatible compatibilists. For both, God's immutable foreknowledge coexists with human responsibility. Erasmus wants to affirm the position of Augustine and Thomas Aquinas. For him, God's will is immutable but he thinks that the deterministic position, as defended by John Wycliffe, is false. Erasmus can affirm divine foreknowledge and immutability while pointing out eonsidering that human will has some freedom. ${ }^{9}$ Luther affirms divine foreknowledge and immutability. Unlike Erasmus, he argues that these doctrines imply a strongly deterministic view of reality. However, Luther defines necessity as immutability. ${ }^{10}$ This is an extremely soft variant of determinism as it basically only holds that everyone who keeps the same course in her actions acts by necessity. Moreover, Luther affirms the view that humans can act more freely when God's grace helps them to cooperate with God. ${ }^{11}$ Philosophically, these views do not differ much from those of Erasmus.

For Luther, however, theological reasoning regarding human freedom is of a certain kind. It leaves philosophical rationalism behind and sticks to the word of God as it has been given to us. Doctrinal teaching does not proceed from philosophical consistency but it reflects biblical correctness. Theologically, Luther teaches that God brings about "life, death, and everything in everything" ${ }^{12}$ Most of this activity is, however, due to God's ineffable and unrevealed will. We have no access to this ineffable will and thus cannot discuss it at all. As a hidden reality, God works in mysterious ways that we cannot and should not consider. In this

\footnotetext{
${ }^{8}$ Erasmus, IIb2.

${ }^{9}$ Erasmus, Ib2.

${ }^{10}$ Luther, Werke (Weimar: Böhlau, 1883-2007, WA), 18: 634.

${ }^{11}$ WA 18: 634-35.

${ }^{12}$ WA 18: 685 .
}

Kommentoinut [GT1]: Is this a philosophical term? If not, I suggest 'compatible' is a better word to use here. Risto: this is ok! 
sense, Luther affirms the old proverbial saying "What is above us, does not concern us." ${ }^{13}$ In other words, we cannot reach a propositional understanding of divine will by means of philosophy. Instead, we need to follow the rule of faith given in Scripture. Common sense and common meanings do not help us in search of theological truth.

Through giving the biblical word, God limits himself Godself with regard to our knowledge. When we hear and read the revealed word of God, it tells us how God works. In this manner we have restricted access to God's will, namely the access given through God's words in Scripture. Luther employs this insight to refute the Erasmian view of freedom as moral responsibility. Luther reads the same biblical passages, claiming that commandment and exhortation do not entail the power to do what is required. Luther grants that people often do what is required by the word of God; however, this doing is in itself prompted by God and corresponds to the commandment for that reason. The biblical word does not, therefore, offer free spaces for human decision-making. Rather, it reports some instances in which the divine will is known and revealed. ${ }^{14}$

Regarding our topic - Luther's reading of Scripture - this means that the word of God illuminates the reality that otherwise remains in darkness. Reason cannot overcome the darkness of theological reality. Moreover, Luther regards reason in divine matters as "blind, deaf, stupid and godless". ${ }^{15}$ Luther grants that God demands impossible things and considers people culpable even when they cannot do otherwise. He eensiders holds that humans

"should be content with the words of God, simply believing what they say, because the works
Kommentoinut [GT2]: Is this last sentence not a little strong? Luther applies a lot of common sense and meanings when he speaks about faith and the church, not least by 'man soll dem Volk auf's Maul schauen' when he translates the Bible. Risto: yes, delete the last sentence. The issue is complicated and need not be explained here.

\footnotetext{
${ }^{13}$ WA 18: 685 .

${ }^{14}$ WA 18: 685-86, 694-95.

15 WA 18: 707 .
} 
of God are incomprehensible". ${ }^{16}$ There is no rational understanding of these matters but an obedience to the text that transforms its readers.

While Luther and Erasmus thus probably have a genuine disagreement concerning the moral status of biblical commands, they both attempt to present a Humanist reading of the text itself, claiming to reach ad fontes. For Erasmus, textual reading means propositional understanding in terms of common sense. An interpreter is obedient to the most obvious reading of the passage. For Luther, however, the biblical text is the only light in the theological darkness of humankind. This text cannot be read with the help of reason or common sense. Such points of comparison are misleading or illusory. They do not give access to the unique content of biblical sentences but only to worldly analogies. Moreover, the biblical word is the only revealed will of God. Therefore, other points of comparison should be judged on the basis of this unique word and not vice versa. The text is a rule of faith that cannot take its meaning from other sources. While Erasmus is an optimist who believes that common sense can illuminate biblical meanings, Luther remains a critical pessimist who relies on the Bible as the rule of faith that is cannot be captured by human reason.

The first-person believer's perspective has a distinctive purpose for Luther in De servo arbitrio. Erasmus interprets biblical personal pronouns like "my good works" or "your wages in heaven" to mean that the subject contributes to these works or wages, thus proving that free will plays some role. For Luther, however, such personal attributions do not imply any personal contribution. Instead, they are to be interpreted as instances of attribution. When I say, for instance, "my hand" or "my feet", I do not mean that I have contributed anything to the event fact of possessing hand or feet. Similarly, the biblical expression "my works" or

${ }^{16}$ WA 18: 708-09. 
"your wages" do not express any idea of personal contribution but simply attribution or appropriation. Theologically, one has not earned one's wages in heaven, but they are simply a gift attributed to oneself. My good works are not mine in the sense of my being the effective agent, but they are mine because the biblical word has attributed and appropriated them to me as gift. ${ }^{17}$

When Luther compares the mode of possessing acts and works to the mode of possessing one's own body, he is in many ways following the classical model of oikeiosis, argued by Cicero. My first persen personal perspective does not emerge because of my activities, but it is due to the observation of the bodily me who is created and preserved by higher powers and only received in my introspection.

Such first-person reading of biblical texts from the perspective of the believer is both clever and clumsy. It is clever because you one can grammatically use the verb "have" and possessive pronouns in the sense of attribution, or gift, without claiming any agency or contribution of our one's own. However, it is also clumsy because such reading does not represent a common-sense understanding of doing something. When I help the needy, a strictly Lutheran view would assume that God helps them, using me as instrument, letting the event to become linguistically attributed to the first person, although in reality God alone is at work. While this can be maintained as a pious theological statement, it hardly describes our everyday usage of possessive pronouns.

Later Protestant debates regarding free will struggle with the viability of such first-person readings. For Luther, the struggle is not, however, philosophical. It rather concerns the reading of the Bible without claiming any propositional understanding in terms of common

${ }^{17}$ WA 18: 695-96. Remarkably, the editor of WA here is not convinced by Luther's argument and adds an opposing footnote! 
sense. While reading "my works" in terms of attribution goes against common sense, this reading is presented as an instance of the theological doctrine of justification by faith, without human works.

III

I will not proceed further into the deep waters of theological free will. I have only used $D e$ servo arbitrio to highlight Luther's basic view of the word of God as our only light and the rule of faith in theological darkness. Some prominent Lutheran hermeneutical doctrines are corollaries of this basic view. In the opening pages of De servo arbitrio Luther outlines his doctrine of claritas scripturae, clarity of Scripture. ${ }^{18}$ The Bible is externally clear, because it reveals the will of God and illuminates everything. Internal clarity can only be achieved through the work of the Spirit. In order to read "my works" as personal merit one would need an internal clarity of the phrase. External clarity, however, allows us to compare the phrase with the overall Pauline language of justification by faith, a view denying the contribution of human works.

Another prominent Lutheran doctrine concerns the ability of Scripture to interpret itself, scriptura sacra sui ipsius interpres. ${ }^{19}$ As the external, revealed word is the only reliable source of theological doctrine, it needs to be interpreted with the help that it provides in its entirety. Instead of reason, context, or common sense, the interpreter needs to expound biblical words with other external, biblical words. This is why readings that go against common sense are sometimes preferred. Since Luther thinks that the Pauline message of justification by faith, without works of the law, guides the understanding of phrases like "my

${ }^{18}$ WA 18: 609.

${ }^{19}$ See Bayer, 74-75. 
works", he prefers the reading according to which the first-person possessive pronoun "my" does not signify agency but merely attribution.

For a modern theologian, such principles and Luther's criticism of Erasmian common sense are somewhat puzzling. There seems to be an inherent textual or revelatory positivism and even legalism involved in Luther's understanding of the Bible. If everything else is darkness, and only the external word shines in this darkness, this word can only be approached in an externalist fashion. At the same time, Lutheran reform programs do not resemble modern fundamentalism. The importance of Bible translations, for instance, assumes that we can understand the biblical message so that it can be translated into another language with the help of common sense meanings.

The issue is complex, as Bible translations are typically Humanist ventures that proceed from an Erasmian view of common sense meanings and the basic idea of translatability between different languages. Luther's revelatory positivism may in some ways resemble more the medieval practice of employing the wordings of the Vulgate as the rule of faith to preserve correct doctrine. On the other hand, Luther often appeals to common sense and ordinary meanings in his programmatic writings about translation. ${ }^{20}$

Luther is neither a fundamentalist nor a typical Humanist. The Lutheran Reformation creates an original variant of the Humanist view of textual interpretation. This view does not rely on the received views of natural or Aristotelian reason but it aims at finding both the content and the method of interpretation from the source text itself. According to this view, each text provides its reader with something like a systemic order, an inherent conceptual map of the issue at hand. This primary order is simply "given" as it does not have any

${ }^{20}$ See Christoph Burger, "Luther's Thought Took Shape in Translations of Scripture and Hymns", in Oxford Handbook, 481-88. 
grounds in common sense or Aristotelian categories. What I call the systemic order resembles the rhetorical concepts and the so-called topoi to an extent, but it is more varied according to the different subject matters. To argue this position convincingly, some historical background is necessary.

\section{IV}

The roots of Luther's view are found in the so-called commonplace books. They were employed already in the medieval period, but became very fashionable in the first decades of book printing. Commonplaces are the concepts printed in the margins of the textbooks so that the reader can visualize and memorize the teachings by means of these heat-key words. As marginal glosses the commonplaces can follow the inner logic of each text, irrespectively of logical or rhetorical structures. For this reason, they describe the text somewhat differently from Aristotelian categories or scholastic divisions. While the Aristotelian method applies the same universal categories to all different texts, the commonplaces catch the flow of each text in a distinctive fashion, condensing its narrative in terms of an individualized set of key words. ${ }^{21}$

The most influential systematic description of this pedagogical and mnemotechnical method is given in Erasmus' De duplici copia verborum et rerum of 1512. In this work, Erasmus introduces and describes the practice which was still in my own student times referred to as the "card box method". The commonplaces should be noted on book margins, but also on loose sheets so that each sheet gives the list of all occurrences of one particular commonplace in different source texts. When this collection grows, "finally, whenever

${ }^{21}$ Here I use Ann Moss, "Morals Stored and Ready for Use", in Rethinking Virtue, Reforming Society, ed. D. Lines \& S. Ebbersmeyer (Turnhout: Brepols, 2013), 169- 87.

Kommentoinut [GT3]: I think 'key word' is what you mean. Is that correct? Risto: yes 
occasion demands, you will have ready to hand a supply of materials for spoken or written composition, because you will have, as it were, a well-organized set of pigeonholes, from which to extract what you want."22

This practice is not only pedagogical and mnemotechnical, but it is also in some ways methodological. Each text has its own set of commonplaces. They are not merely external to the text but represent its inner flow or argumentative order. This methodological side is reflected in more detail in Erasmus' Ratio verae theologiae of 1518. In this work, Erasmus advises the reader of biblical books to collate "theological loci in which you place everything you read as if in certain little nests". The reader can further arrange these topics in organic or systematic relationships according to their similarities and differences. Through this procedure, all significant features of different biblical books can be highlighted in the manner they deserve. ${ }^{23}$

In biblical texts, however, it is not enough to attend only to the various commonplaces. They are organized according to an underlying holistic principle which Erasmus calls the scopus of the entire text. For Erasmus, Jesus Christ is the scopus of biblical theological texts. This means the life and acts of Christ rather than any particular doctrine. The doctrines are represented through the various loci or commonplaces. Singular biblical passages can be subsumed under generic commonplaces, and they all finally serve the overall scopus. Thus we have different nests with their small inhabitants, but also the overall ecosystem, the scopus that provides the organizing principle of individual nests.

\footnotetext{
${ }^{22}$ Erasmus, De duplici, quoted from Moss, 171.

${ }^{23}$ Erasmus, Ausgewählte Schriften 3: 64-67. Translation and interpretation by Risto Saarinen, "Reclaiming the sentences: a linguistic loci approach to doctrine," Neue Zeitschrift für systematische Theologie und Religionsphilosophie 54 (2012): 1-22, here: 9.
} 
The first commonplace book of the Reformation, Melanchthon's Loci communes of 1521, takes over the method of Erasmus, developing it towards theological epistemology. Also for Melanchthon, Christ and his beneficial deeds provide the scopus that sustains the different loci so that they together make the doctrina Christi. Melanchthon takes his commonplaces mostly from Paul's Letter to the Romans. For him, they are not very many. Sin, law, grace and faith are among the most important commonplaces. ${ }^{24}$

While the methodological procedure of Melanchthon resembles that of Erasmus, one can also see differences between them. Like Luther, Melanchthon highlights the first persen perspective of the believer and does not consider it to mean any subjective contribution or agency of the Christian. Like Luther, Melanchthon considers that only canonical Scripture is valid as the ground of theology. Like Luther, Melanchthon does not rely on common sense or worldly wisdom but considers points out that theologians must learn everything from the Bible. The biblical rule of faith illuminates other matters, but there are no external criteria that could be applied to the biblical word.

In this manner, Melanchthon's Loci communes represents the distinctive kind of critical and pessimistic Humanism that is typical of early Lutheranism. The modern scholar needs to see that this variant is not flatly fundamentalist. It builds on the assumption that the biblical text contains different layers so that a functional set of commonplaces and an overall systemic order regarding the scopus emerge. While these ideas are shared by Erasmus, Melanchthon emphasizes the evidence-based approach. He gathers the scriptural evidence and organizes it into the main commonplaces. This procedure is supposed to take place intrabiblically, without the aid of philosophy, common sense, or other external criteria. What

${ }^{24}$ Philipp Melanchthon, Loci communes 1521 Lateinisch-Deutsch (Gütersloh: Gerd Mohn, 1993). This edition offers good commentaries by H. G. Pöhlmann. 
emerges as a result of this evidence-based approach is the system of loci that has Christ as its overall scopus.

$\mathrm{V}$

Through his entire career, Luther lectured on biblical books at the university and preached from the pulpit. We have numerous examples of his reading and exposing biblical texts. However, Luther did not draft methodological of or hermeneutical writings similar to those of Erasmus and Melanchthon. Modern studies on Luther's hermeneutics normally focus on explaining some leading principles which can often be expressed as well-known slogans.

We have already mentioned some of these slogans, namely: (1) sola scriptura: all Christian teaching must be learnt from the Bible alone. (2) Claritas scripturae: the Bible is clear and can be understood without external aids. (3) Scriptura sacra sui ipsius interpres: the Bible exposes itself, or the Bible can be understood in terms of its own totality. (4) First persen The believer's perspective: we must apply the word of God to ourselves. This slogan is also close to the centrality of justification by faith and personal salvation in Luther.

Other well-known principles of Luther include the following: (5) was Christum treibet:

Christ is the center or the scopus of the Bible, and the Bible needs to be interpreted so that it focuses on Christ. (6) Law and gospel: the Bible contains twofold material: some of it treats commandments of the law, whereas other parts include promises and inform us about the grace and the gospel. (7) The spirit and the letter: this Augustinian maxim is often understood as the distinction between (8) spoken and written word. This distinction has sometimes been interpreted as the difference between the living word of God and the written 
Scripture. In some sense, the spoken word has priority, but the relationship between the two is complex. For instance, the doctrine of clarity emphasizes the written, external word. ${ }^{25}$

In this manner, we have a variety of hermeneutical rules applied by Luther in his reading of Scripture. The real problem is to construct an overall theory of interpretation with the help of all these rules and slogans. While they do not contradict one another, they are often fragmentary rules of thumb that need to be expanded towards any systematic theory of interpretation. In the following, I will, nevertheless, attempt to outline such a systematic theory. While it aims at following Luther's central tenets, it also adds more systematic structure than is available in the historical Luther.

\section{VI}

Historically, Luther's method of reading Scripture is fairly close to the commonplace method of Erasmus and Melanchthon. Like his Humanist colleagues, Luther considers Christ to be the scopus of Scripture. Luther does not employ the idea of loci communes consistently, but he assumes that there are intermediate cluster concepts between the overall scopus and the individual written words, sentences and narratives. For instance, law and gospel can be understood as commonplaces; Melanchthon treats them as such. Categories like sin, promise, justification, faith and works are likewise typical commonplaces. With the help of such cluster concepts, different biblical narratives can be subsumed under the same heading, like the different sheets in Erasmus' card box method.

The two cluster concepts of Scripture and the word of God may be revealing in this regard, although they still need more study. Scholars typically argue that there is a difference between the two clusters, Scripture referring to the written word of the Bible, maybe in

\footnotetext{
${ }^{25}$ For the totality of these principles, see Bayer, 68-92.
} 
particular the Old Testament, the word of God often referring to the event of preaching the gospel that is available especially in the Pauline epistles. ${ }^{26}$ However, these two cluster concepts often overlap in Luther's writings. In addition, the entire semantic field of doctrina in the Reformation is complex. Sometimes doctrina means written doctrine or confession, sometimes oral teaching or proclamation. Often it means both in an inseparable unity, within which nevertheless some conceptual distinctions can be made. ${ }^{27}$

My own claim is that the relationship between the word of God and Scripture is a relationship of emergence and that it resembles the relationship between the commonplaces and the text. The word of God emerges from Scripture with a sort of inevitable necessity: a sincere reader cannot come to any other conclusion than that this is a book about sin and grace, law and gospel. Finally, it is a book about Christ and his work for us. In this manner, Scripture is clear and it exposes and explains itself. However, the commonplace doctrines need to emerge from the text. Unlike Erasmus, Luther does not rely on common sense and rational analogies. Instead, he thinks that the Bible is proactive, giving birth to the correct readings by itself. Such self-efficiency of Scripture has sometimes been understood as an aspect of self-interpretation. ${ }^{28}$

Self-interpretation and self-efficiency need not be strange or magical hermeneutical doctrines. The Humanist view of commonplaces assumes that texts have a natural organization and that they imitate nature. Commonplaces extracted from the text are no political decisions or deliberate constructions but themes that naturally emerge from the text, guiding its interpretation. Good coherent texts are self-interpretative and self-effective in the

\footnotetext{
${ }^{26}$ For these terms, see Christoph Schwöbel, "Bible IV," in Religion Past and Present 2 (2007), 13-17.

${ }^{27}$ The best new study of this is P. Büttgen et al. (ed.), Vera doctrina: Zur Begriffsgeschichte der Lehre von Augustinus bis Descartes (Wiesbaden: Harrassowitz, 2009).

${ }^{28}$ Bayer, 74-77.
} 
sense that you can reach a consensus with regard to which themes capture the flow of the text adequately. Biblical texts deviate from the natural course of the world and are thus not open to common sense in the same manner. We may, however, think with Luther that their inherent systemic order is given by God so that the commonplaces of sin, law and grace as well as the Christocentric scopus emerge inevitably from the biblical text.

This emergent relationship between doctrinal commonplaces and scriptural text is, I think, a basic assumption in some well-known features of Lutheranism. The theory of preaching assumes that one hears the word of God from the pulpit. The pastor typically organizes the biblical text in terms of commonplaces so that the living word of God interacts with the text. The commonplaces are entirely based on the text; at the same time, they are emergent concepts which make the text a living word of God. Another typically Lutheran and Protestant feature is that the Bible can in some ways replace the magisterium as an instance of doctrinal interpretation. ${ }^{29}$ This bold claim results from the assumed capacity of selfinterpretation and self-efficiency. I am ready to grant that not everything in the magisterium or episcopacy can be replaced with this claim. However, one needs to see that the authority of the Bible is a practical and operative authority.

\section{VII}

Systematically, we can discuss Luther's view in terms of a theory of doctrine. This is a modern discussion initiated by George Lindbeck and has continued until the present day. ${ }^{30}$ If we ask very generally whether the primary natural vehicle of theological doctrine is personal experience, reason or language, Luther's view most likely would consider language as such a

${ }^{29}$ Cf. Christoph Schwöbel, "Revelation V2b," in Religion Past and Present 11 (2012), 172-73.

${ }^{30}$ George Lindbeck, The Nature of Doctrine (Philadelphia: Westminster, 1984). Christine Helmer, Theology and the End of Doctrine (Louisville: Westminster John Knox, 2014). 
vehicle. The first-person perspective of the believer gives personal experience some role, but only in encountering the primary reality of the word. As the linguistic reality of Scripture cannot be adequately approached with common sense or Aristotelian reason, Luther's view is to be labeled as a rule theory of doctrine. The language of the Bible gives provides the rules of theological doctrine without much regard to logical categories or common sense.

What basic rules does the description given above apply? First, it obviously employs a language restriction rule. All theological knowledge is based on biblical revelation. This rule needs many kinds of differentiations. On the one hand, it says that the biblical way of speaking is how true theology is articulated promeed. On the other hand, there is probably room for considering how analogies to other ways of speaking are possible so that, for instance, translations can be made and new issues not mentioned in the Bible can be encountered in responsible fashion. ${ }^{31}$

The second basic rule can be labeled as a rule of systemic order. This rule says that the authoritative text has a certain inherent pattern or order which enables its own coherent interpretation. The loci method captures such systemic order, as the text has its own basic concepts and an overall scopus which most readers can detect. The concepts or themes emerge from the text by their own right, guiding its interpretation. The rule of systemic order is in some ways connected with a hermeneutics of trust. It does not consider the text to be simply raw material for later constructions but a coherent totality which can guide and preserve its own interpretation. The rule is, however, not naive but allows a variety of interpretations. We might say, using a non-biblical example, that one can interpret Shakespeare's Romeo and Juliet in many different ways, but claiming that there is no love story involved would go against the rule of systemic order.

\footnotetext{
${ }^{31}$ See in more detail Saarinen, "Reclaiming", 17-18.
} 
The rule of systemic order maintains that texts contain clues regarding their own interpretation. In practice, this means the availability of scopus and some loci that are given by the source text itself rather than any general methodology external to the text. In this manner, the rule of systemic order is critical of abstract philosophical and scholastic principles. It relies on a Humanist congeniality to the text. Obviously, the issue is complex. I do not maintain that even very coherent texts can entirely control later interpretations. But I do claim that the text is not simply a victim of its later users or an empty table to which the power-holders can ascribe all kinds of meanings. A coherent text has such systemic order that equips it with considerable self-efficaciousness and internal criteria to distinguish between adequate and less adequate later readings. ${ }^{32}$

The concept of rule may also be illuminating in this regard. Rules are by their very nature proactive as they inform and control the reality. If epistemic pessimism is connected with a rule theory of theological sentences, the relative control of reality increases, as everything else is assumed to remain in darkness and thus cannot provide competing criteria to the given rules.

Generally speaking, Luther reads the Bible in terms of a rule theory rather than propositional understanding. The debate between Erasmus and Luther offers remarkable evidence for this view. Erasmus clearly wants to understand biblical sentences with the help of common sense. For Luther, however, propositional understanding is often misleading or even a trick of worldly reason. Luther wants to listen to the biblical language as a rule of faith, a rule that gives its own interpretation from the totality of the linguistic source.

Therefore he often abandons common sense readings and claims that God is hidden, or even hidden under the opposite. The linguistic expressions of this idea cannot be read as mental

${ }^{32}$ Saarinen, "Reclaiming", 15-16. 
propositions involving a philosophical truth theory, but they are to be understood as sentential rules, the peculiar way of speaking in theology.

To say that Luther adheres to a rule theory of biblical doctrine does not make the Reformer modern in any particular way. The idea of regula fidei is a classical view of doctrine, and one can have more or less fideistic variants of this idea. The assumption that the rule of faith can express doctrine in terms of commonplaces and overall scopus moderates fideism and literalism considerably. Both Erasmus and Luther grant the human mind an ability to grasp central teachings of Scripture, although the dynamics of this ability is rulebased in Luther and common sense-based in Erasmus.

Neither can the rule theory be called particularly Protestant. If we look at the Ratio studiorum of the Jesuits order from the late 16th century, we may read some advice that is very similar to Luther's views. The biblical scholar is advised "not to use scholastic method in questions peculiar to Holy Writ." "In order to ascertain the genuine sense of Holy Writ, he must note the idiomatic expressions and figures of speech peculiar to Scripture. He must skillfully compare the passage he is reading not only with that which precedes and follows but also with other passages where the same phrase will have sometimes the same, sometimes a different meaning." 33

Given that this passage from the Ratio studiorum is representative of Catholic biblical scholarship, we need not be afraid of Luther's confessional slogans. In fact, many of these slogans belong to the broader Humanist current of early modern Western theology that was shared by different churches. They are signposts for reading Scripture in responsible and authentic fashion.

${ }^{33}$ Ratio studiorum (1599), transl. A. Farrell, (www.bc.edu/sites/libraries/ratio/ratio/1599.pdf), 30-31.

Kommentoinut [GT5]: Does "In order..." follow directly after the previous sentence? If yes, there should not be any inverted commas. If not, three dots need to be inserted. Risto: please insert the three dots 